\title{
УПРАВЛІННЯ ЗДОРОВ'ЯМ ПРАЦІВНИКІВ ЯК СУЧАСНИЙ ІНСТРУМЕНТ ОХОРОНИ ТА ОРГАНІЗАЦІЇ ПРАЦІ
}

\section{EMPLOYEE HEALTH MANAGEMENT AS A MODERN TOOL OF LABOR PROTECTION AND ORGANIZATION}

\author{
Сорока Олександра Володимирівна \\ кандидат економічних наук, доцент, \\ Одеський національний економічний університет \\ ORCID: https://orcid.org/0000-0001-6982-1817 \\ Сало Яна Вікторівна \\ кандидат економічних наук, старший викладач, \\ Одеський національний економічний університет \\ ORCID: orcid.org/0000-0003-1066-783X
}

\author{
Soroka Oleksandra, Salo Yana \\ Odessa National Economic University
}

Питання підтримки і зміцнення професійного здоров'я набувають особливої значущості через змін, що відбуваються, концентруючи сьогодні необхідність створення умов для досягнення професійного довголіття. Стаття присвячена розгляду питання збереження і самозбереження професійного здоров'я працівників. Представлені результати наявних в зарубіжній практиці програм управління професійним здоров'ям. Встановлено, що за кордоном дані програми мають тривалу історію своєї реалізації, на відміну від вітчизняної практики управління. Розглянуто поняття професійного здоров'я і розкрито його актуальність. Визначено соціально-психологічні аспекти управління професійним здоров'ям. Підкреслено необхідність впровадження корпоративної системи управління здоров'ям співробітників, розкривається, наскільки це може бути економічно вигідно для організацій і корисно для співробітників.

Ключові слова: здоров'я персоналу, охорона праці, організація праці, корпоративні програми зміцнення здоров'я, робоче місце, умови праці.

Вопросы поддержания и укрепления профессионального здоровья приобретают особую значимость по причине происходящих изменений, актуализирующих сегодня необходимость создания условий для достижения профрессионального долголетия. Статья посвящена рассмотрению вопроса сохранения и самосохранения профессионального здоровья работников. Представлены результаты имеющихся в зарубежной практике программ управления профессиональным здоровьем. Установлено, что за рубежом данные программы имеют длительную историю своей реализации, в отличие от отечественной практики управления. Рассмотрено понятие профрессионального здоровья и раскрыта его актуальность. Определены социально-психологические аспекты управления профессиональным здоровьем. Пподчёркивается необходимость внедрения корпоративной системы управления здоровьем сотрудников, раскрывается, насколько это может быть экономически выгодно для организаций и полезно для сотрудников.

Ключевые слова: здоровье персонала, охрана труда, организация труда, корпоративные программы укрепления здоровья, рабочее место, условия труда.

The main goal of any commercial organization is to generate profit, build financial capacity and maximize income. Important in this process is the work of the company's management to find any opportunities to reduce its costs. But nevertheless, the functioning of the organization is impossible without the use of human resources, their development in the future. The issues of maintaining and strengthening professional health acquire special significance due to the ongoing changes, which actualize today the need to create conditions for achieving professional longevity. The article is devoted to the consideration of the issue of preservation and self-preservation of workers' professional health. The results of professional health management programs available in foreign practice are presented. It was found that abroad these programs have a long history of their implementation, in contrast to the domestic management practice. In Ukrainian companies, concern for employees, the development of corporate policy as a strategy for the future has not yet become ubiquitous. Many are looking for benefits in downsizing, lower wages, temporary employees, and effective 
management decisions. Objectively, companies want instant results without long-term and ambiguous investments. Meanwhile, in foreign countries, health management programs are reaching a new, progressive level, which provides not only for improving working conditions, but also for holding Health Days, changing the lifestyle of employees (promoting a healthy lifestyle, adjusting nutrition programs, increasing physical activity, etc.), as well as regular monitoring and monitoring of the health of employees. For many corporate health management systems in organizations, the period has come to reassess the system of work and develop new solutions. The concept of professional health is considered and its relevance is revealed. The socio-psychological aspects of occupational health management have been determined. The necessity of introducing a corporate health management system for employees is emphasized, it is revealed how it can be economically beneficial for organizations and useful for employees.

Keywords: staff health, labor protection, labor organization, corporate health promotion programs, workplace, working conditions.

Постановка проблеми. Питання збереження і підтримання професійного здоров'я працівників останнім часом набувають особливої значущості і обумовлені змінами, що відбуваються. Серед найбільш значущих можна відзначити наслідки глобалізації, які привели до перетворення всього світу і того середовища, в якому здійснює свою діяльність організація. Для сучасної ситуації характерними рисами стають нестійкість, невизначеність, гнучкість, пристосовність, висока швидкість змін і ін. Також слід зазначити і зміну вікових характеристик людей працездатного віку за рахунок збільшення віку виходу на пенсію. Так, за прогнозами ООН до 2050 року чисельність населення світу у віці 65 років і старше більш ніж подвоїться [1]. Тому вже зараз необхідно змінювати традиційні уявлення про роль віку в праці, проектувати нові підходи до організації праці, оцінки діяльності працівників і т. д. У зв'язку з цим стає своєчасним пошук відповіді на питання - яким чином можливо зберегти профресійне здоров'я працівника і за рахунок цього продовжити період активної працездатності? Актуальність проблеми управління здоров'ям співробітників виходить на новий рівень, організації прагнуть розвивати систему управління здоров'ям свого персоналу, щоб максимально використовувати людські ресурси, реалізовувати потенціал своїх цінних кадрів.

Аналіз останніх досліджень і публікацій. Аналіз літератури засвідчує, що вивчення певних аспектів здоров'я особистості знайшло відображення в роботах зарубіжних та вітчизняних учених, у яких розкрито сутність психологічного здоров'я та його види (I.В. Дубровіна, В.Е. Пахальян, Ж.В. Сидоренко та ін.). Також розроблено окремі методики для дослідження психологічного здоров'я (А.В. Козлов, А.М. Шевченко та ін.). Що стосується здоров'я персоналу організації, то ця проблема знайшла значно менше відображення, зокрема, в роботах вітчизняних учених.

Метою статті $\epsilon$ обґрунтування доцільності і визначення особливостей застосування корпоративних програм управління здоров'ям персоналу як сучасного інструменту і охорони та організації праці.

Виклад основного матеріалу. Працюючі складають половину світового населення і вносять основний внесок в економічний і соціальний розвиток. Ïх здоров'я визначається не тільки тими ризиками, які присутні на робочому місці, а й соціальними та індивідуальними фракторами, а також доступом до медико-санітарних послуг.

Стосовно до працюючих виділяють профресійне і корпоративне здоров'я. Профресійне здоров'я розглядається як здатність організму працюючої людини забезпечувати високу і тривалу працездатність, а також професійне довголіття в умовах його професійної діяльності [2; 3].

Під корпоративним здоров'ям розуміють одну з компонентів корпоративної культури організації (компанії), що забезпечує поряд с збереженням і поліпшенням здоров'я, благополуччя і працездатності працівників підвищення есрективності їх діяльності та підтримання високого іміджу організації. Принципово обидва ці визначення об'єднує необхідність в зміцненні здатності організму працівника зберігати компенсаторні і захисні властивості і резерви, що забезпечують його високу працездатність при виконанні ним профресійних ффункцій. 3 точки зору авторів статті, вони мають певну ідентичність і можуть певною мірою використовуватися як синоніми.

У сучасних соціально-економічних умовах збереження трудового довголіття $€$ пріоритетним напрямком діяльності фрахівців 3 охорони та медицини праці. Зниження ймовірності передчасної смерті від неінфекційних захворювань веде до збереження трудового потенціалу [4]. Гарантії охорони здоров'я та створення безпечних умов праці встановлені законодавчо, а також можуть бути закріплені колективним договором. Будь-яка праця несе потенційний ризик здоров'ю [5-7].

Health management (в перекладі 3 англійської - управління здоров'ям персоналу) - це сукупність заходів, тренінгів, акцій і програм, що спрямовані на поліпшення і підтримку здоров'я співробітника. Дана концепція заро- 
дилася у1970-х роках і до 1990-х років поширилася вже по всій Європі.

Здорові співробітники - головний актив успішної компанії. У розвинених країнах управління здоров'ям персоналу є одним з пріоритетних методів зниження витрат компанії і мотивації працівників. Healthcare management стає все більш популярним останнім часом серед сучасних компаній.

За кордоном healthcare management - це невід'ємний елемент корпоративної системи. Раніше впровадження даної концепції входило лише до обов'язків HR-менеджера, але зараз це самостійна галузь, яка містить великий набір фрункцій, за якої стежить окремий кваліфрікований співробітник.

У срункції системи входять щоденна перевірка здоров'я співробітників, проведення періодичних профрілактичних оглядів, срінансування психологів, тренерів і нутриціології, розробка програм оздоровлення та боротьби зі шкідливими звичками, а також оцінка ризиків і планування. Збереження профресійного здоров'я передбачає надання допомоги і підтримки працівникові, який знаходиться в різних соціальнопрофресійних ситуаціях, в тому числі і несприятливих, і передбачає гармонізацію внутрішнього стану людини і зовнішніх умов професійної діяльності. Відповідно, основна роль відводиться керівному складу організації, від якого залежить створення психологічно комфрортного та безпечного профресійного середовища.

Вищесказане визначає зміст технологій збереження і самозбереження професійного здоров'я працівників. Слід зазначити, що до теперішнього часу склалися деякі тенденції щодо даних аспектів в зарубіжній і вітчизняній практиці. 3 огляду на, що професійне здоров'я працівників сьогодні один 3 важливих ресурсів організації, то стає важливим визначення можливих напрямків роботи і змісту конкретних способів і прийомів по його збереженню і самозбереження. На підставі цієї інфрормації буде можливо розробити програму управління профресійним здоров'ям.

Помітно більший досвід в галузі розробки і впровадження програм збереження і зміцнення профресійного здоров'я накопичений в зарубіжних країнах, оскільки створюватися і впроваджуватися в практику вони стали 3 70-80-х рр. XX століття. Слід зазначити, що спочатку дані програми носили фррагментарний характер і включали в себе окремі заходи. До теперішнього часу дані програми створюються на рівні держав і корпорацій. При цьому, в різних організаціях робляться акценти на різних аспектах здоров'я.
Розглядаючи програми Health management, що застосовуються в західних організаціях, можна виділити ряд модулів, які включаються в їх зміст [8]:

- інфрормаційно-діагностичний, який передбачає інорормування працівників (лекції, бесіди) і оцінку індивідуального здоров'я працівників;

- відновлювально-профрілактичний, що полягає в розробці індивідуальних програм розвитку здоров'я працівників.

У перелік послуг, що надаються в рамках програм Health management також включаються: стрес-менеджмент та стрес-аудит, реабілітаційні програми, тренінгові програми, планування корпоративного здоров'я, ергономічна оцінка робочих місць, тестування на алкогольну і лікарську залежність, «програми управління імунітетом» і т. д.

Найпоширеніші програми Health management об'єднуються в два напрямки:

1. дослідження медичних ризиків (виявлення і ранжування за значимістю фракторів, що негативно позначаються на здоров'ї працівників; вивчення статистики по найбільш частих захворюванням, встановлення їх причин і наслідків, проведення стрес-аудиту) [9];

2. планування профрілактичних заходів щодо зниження захворюваності співробітників (регулярні медичні огляди; добровільне медичне страхування; компенсація оплати відвідування фрітнес-клубів; мотиваційні програми, що заохочують здоровий спосіб життя, зокрема, відмова від куріння, здорове харчування; ергономіка і екологія офрісних приміщень) [10].

Отже, аналіз зарубіжного досвіду засвідчує, що до теперішнього часу склалася практика розробки і застосування програм, що спрямовані на збереження профресійного здоров'я працівників, в основному адаптованих під умови конкретної організації і діючих на організаційному рівні. Зміст даних програм включає в себе різні заходи, що спрямовані на підтримку фрізичного і психічного стану, забезпечують високий рівень працездатності. У змісті даних програм поєднується вплив на фрізичні і психологічні складові здоров'я.

Корпоративні програми зміцнення здоров'я працівників передбачають комплекс заходів, що вживаються роботодавцем для поліпшення стану здоров'я працівників, поліпшення мікроклімату в колективі, в цілях профрілактики захворювань, підвищення безпеки, продуктивності і ефективності праці працівників організації (компанії). Слід зазначити, що корпоративні програми зміцнення професійного здоров'я працівників - це важливий компонент системи охорони здоров'я працюючих. Необхідно також підкреслити, що 
корпоративні програми зміцнення здоров'я є проявом соціальної відповідальності роботодавця і його інвестиціями у трудові ресурси організації (компанії). Таким чином, зміцнення профресійного здоров'я працівників передбачає фрормування на виробництві здоров'язберігаючих умов, що сприяють зменшенню ймовірності виникнення як профресійно детермінованих захворювань, так і соціально значущих хронічних неінфекційних захворювань. Певна частина смертей від неінфекційних захворювань обумовлена недотриманням принципів здорового способу життя і наявністю ряду шкідливих звичок: тютюнопаління, зловживання алкоголем, нездорового харчування і малої фрізичної активності [11; 12].

Корпоративна система управління здоров'ям у наш час - це комплекс програм і заходів, спрямованих на зміцнення здоров'я співробітників що мають величезну кількість різноманітття і специфріки $[13$, с. 7].

3 точки зору користі для компаній ідея використання корпоративної системи управління здоров'ям і пропаганда здорового способу життя має кілька важливих ролей.

1. Потужна мотивація. Як показують дослідження, створення корпоративної системи управління здоров'ям безпосередньо впливає на показники працездатності, а також на рівень здоров'я співробітників. Турбота про здоров'я персоналу, що включає в себе програми всередині організації, є частиною соціального пакету працівника, а це $є$ одним 3 найважливіших чинників привабливості компанії як роботодавця. Також впровадження корпоративної системи управління здоров'ям сприяє підвищенню лояльності як самого співробітника до компанії, в якій він працює, так і його сім'ї до його місця роботи, що є стратегічно важливим елементом мотивації працівника і довгостроковості роботи в цій організації, оскільки людина приблизно половину свого активного часу проводить на роботі, то вона повинна відповідати таким параметрам, як безпека, комфорт, схвалення з боку близьких [14, с. 58].

2. «Особлива» корпоративна культура. Концепція управління здоров'ям співробітників створює відмінну внутрішньоорганізаційну культуру, що має свої особливості. Часто різні програми і заходи, що реалізуються в рамках корпоративної системи управління здоров'ям, мають командоутворюючий, що згуртовуючий ефект, що дозволяє створити сприятливий соціально-психологічний клімат в колективі, налагодити взаємозв'язок і комунікацію всередині організації. Дні здоров'я, спортивні заходи та гуртки створюють не просто суспільство колег, а друзів у робочому колективі, сприяють підви- щенню мотивації та зацікавленості співробітників в життя компанії, а також дозволяють максимально розкрити потенціал працівників.

3. Імідж організації як привабливого роботодавця. Компанії, які особливу роль віддають ідеї управління здоров'ям своїх співробітників і здорового способу життя, в порівнянні з іншими організаціями, рівними їм за іншими умовами, будуть більш привабливим місцем роботи для претендентів. Багатоцінні фрахівці і профресіонали шукають ту організацію, в якій їм буде найбільш комфортно працювати і розкривати свій потенціал, стежити за своїм здоров'ям далеко не тільки заради задоволення первинних потреб. Важливо відзначити, що створення власного HR-бренду є одним з найбільш цікавих i важливих напрямом роботи HR-менеджерів. Багато компаній вкладають величезні фрінансові кошти, щоб роздобути імідж привабливого роботодавця, якому не доводиться шукати персонал. У такі компанії люди потрапляють за власною ініціативою [15, с. 15].

4. Соціальна відповідальність роботодавця. Пропагуючи ідею турботи про здоров'я співробітників, організація береться за важливе і копітке заняття на довгостроковій основі. Але прикладати такі зусилля необхідно, тому що в компанії у людини фрормуються певні звички, які залежать від корпоративної культури і традицій. Покладаючи на себе соціальну відповідальність, компанія прагне до довгострокового ефректу, такого як, наприклад, зниження кількості днів за лікарняним листком. Також велику роль відіграє діючий соціальний пакет, який надає власним працівникам компанія. Саме він служить еталоном ідеї корпоративного управління здоров'ям і відображає те, які переваги має компанія як роботодавець, який піклується про здоров'я свого персоналу Слід зазначити, що робота над змістом соціального пакета безпосередньо відноситься до тієї корпоративної системи управління здоров'я, яка існує в організації на даний момент і впливає на задоволеність і вмотивованість співробітників.

Вигоди для працівників від впровадження програм з підтримки здоров'я на робочому місці:

1) Зниження ризику придбання хронічних захворювань.

2) Поліпшення психоемоційного стану.

3) Відмова від шкідливих звичок.

4) Підвищення задоволеності від роботи.

5) Часта інфрормованість про своє здоров'я.

6) Розвиток навичок визначення захворювань на ранній стадії.

7) Почуття приналежності до компанії (працівник відчуває, що про нього піклуються). 
8) Поліпшення умов праці.

Слідвраховувати, щоприродаіндивідуальних властивостей людини носить двоїстий характер: її інтереси, вміння, схильності та навички піддаються зміні, а ось психофрізіологічні особливості змінити практично неможливо [16, с. 52]. Тому в основному корпоративні програми управління здоров'ям співробітників діляться на два типи: спрямовані на фрормування здорового способу життя та спрямовані на управління процесом хвороби. Вони відображають різні концепції роботи з управління здоров'ям - концепцію профрілактики і концепцію лікування [14, с. 39]. В ідеальній організації вони повинні здійснюватися в комплексі, забезпечуючи тим самим благополуччя співробітників.

Автори статті також наголошують, що в основі реалізації корпоративного управління здоров'ям співробітників повинні лежати наступні принципи і заходи:

1) виявлення фракторів ризику (проведення опитувань, анкетування, медичних оглядів, які допомагають надати співробітнику інсрормацію щодо його чинників ризику і дозволяють сформувати потребу, пріоритети і напрямки розвитку корпоративних систем управління здоров'ям);

2) пропаганда здорового способу життя та умов для його ведення (пропаганда через корпоративні стінгазети, корпоративні сайти, листівки та пам'ятки, проведення індивідуальних бесід, презентацій і конфреренцій; введення Днів здоров'я, корпоративних спортивних заходів і т. п.);

3) поліпшення стану здоров'я і самопочуття співробітників (надання корпоративних знижок на лікування, послуг психолога і т. п.);

4) проведення заходів і програм, спрямованих на боротьбу з найпоширенішими проблемами;

5) наставництво (використання наставництва як мотиваційного стимулу і приклад для наслідування, актуалізація проблем здоров'я співробітників і супровід) [14, с. 129].

Завдяки використанню цих фрункцій HR-менеджери можуть досягти більш високого рівня залученості співробітників в ідею корпоративного здоров'я і ведення здорового способу життя як цінності компанії. Активізація просування корпоративних програм здоров'я в рамках корпоративної системи управління здоров'ям співробітників компанії повинна реалізовуватися за допомогою наступних ефективних методів:

- регулярних корпоративних розсилок на особисту пошту співробітників, в яких пропонується докладніше ознайомитися з інфрормацією щодо діючих оздоровчих програм в компанії;
- поширення брошур і листівок, що містять інфрормацію про оздоровчі програми, ведення здорового способу життя та рекомендації щодо нього;

- проведення та масової розсилки агітаційних і профрілактичних презентацій, відеороликів на тему здоров'я, правильного харчування і сну, стресу і фрізичних навантажень;

- створення міні-бібліотек з розділами, що присвячені темі самооздоровлення і т. п.;

- агітації через корпоративні соціальні мережі за допомогою публікації постів і статей на відповідні теми $[17$, с. 58].

В цілому вищим топ-менеджерам і всім, хто стоїть на чолі управління компанії, необхідно адекватно оцінювати важливість і ефрективність використання фрілософрiї «healthcare program», що сприяє вирішенню актуальних проблем співробітників сучасних організацій.

Корпоративні програми зміцнення здоров'я це інвестиційний проект, учасникамиякого виступають роботодавець-працівник, як елемент корпоративної культури і програми лояльності в системі управління персоналом і досягненні конкретних вимірюваних результатів. Метою корпоративних програм зміцнення здоров'я на робочому місці має бути підвищення економічної ефрективності поведінки співробітників.

У довгостроковій перспективі компанії, що впроваджують корпоративні програми зміцнення здоров'я працівників стають потенційно більш успішними, більш стійкими і ефективними.

Висновки. Корпоративна система управління здоров'ям співробітників - це найважливіша складова роботи з персоналом організації, яка $€$ актуальною сфрерою для розвитку в багатьох компаніях. Ефективні HR-менеджери на сучасному етапі зобов'язані володіти основами управління здоров'ям співробітників, вміти складати корпоративні програми оздоровлення, виявляти ризики та забезпечувати комплексну і цілеспрямовану роботу по створенню «здорової» організації. Здоров'я - найважливіший ресурс, яким володіє людина, а люди - найцінніший ресурс організацій. У сорері управління здоров'ям цілі компанії безпосередньо збігаються з цілями співробітників. В інтересах компанії скоротити витрати на персонал і підвищити продуктивність праці, що, безумовно, можливо здійснити за допомогою впровадження корпоративних програм оздоровлення. Співробітники зі свого боку хочуть працювати в комфортних умовах, де панує сприятливий соціально-психологічний клімат, створено умови для турботи про себе і здоров'я. Саме це досягається завдяки про- 
суванню в компанії healthcare program (корпоративної системи управління здоров'ям) і wellbeing program (програм благополуччя), які спрямовані на створення програм з оздоровлення співробітників і на досягнення балансу між фрізичним, емоційним і фрінансовим благополуччям, а також на формування усвідомленого ставлення співробітників до власного здоров'я.

У Україні healthcare program - це нова i незвична фрілософрія, яку слід впроваджувати і розвивати. HR-менеджери мають можливість підвищити значимість роботи 3 персоналом для вітчизняних підприємств, просуваючи ідею турботи і оздоровлення співробітників. Корпоративне управління здоров'ям співробітників відкриває шлях довгострокового ефректу, який визначає стабільність і успішність організації. Використовування зазначених програм допомагає роботодавцям підвищити власний імідж, сприяють розвитку HR-бренду, зміцнюють корпоративну культуру і створюють індивідуальність компанії. Здоров'я співробітників - це перспективне вкладення в майбутнє кожної організації, до того ж такі інвестиції сприяють зниженню витрат і порожніх витрат фрінансів компанії. Впровадження корпоративних програм оздоровлення покликане допомагати роботодавцям у вирішенні відкритих і наболілих кадрових питань. Сучасні корпорації давно реалізують корпоративне управління здоров'ям співробітників і цілеспрямовано розвивають цю систему, усвідомлюючи, що співробітників необхідно не тільки лікувати, але і вчити бути здоровими.

\section{СПИСОК ВИКОРИСТАНИХ ДЖЕРЕЛ:}

1. Щербакова Е.М. Население мира по оценкам ООН пересмотра 2019 года. Демоскоп Weekly. 2019. № 821-822. URL: http://demoscope.ru/weekly/2019/0821/barom01.php (дата звернення: 21.09.2021).

2. Разумов А.Н., Пономаренко В.А., Пискунов В.А. Здоровье здорового человека (Основы восстановительной медицины) / под ред. В.С. Шинкаренко. Москва : Медицина, 1996. 413 с.

3. Ушаков И.Б., Арутюнов А.Г., Шерешков Г.М., Турзин П.С. Введение в авиационную медицину. Москва; Воронеж, 2002. $350 \mathrm{c}$.

4. Масленникова Г.Я., Оганов Р.Г. Профрилактика неинсекционных заболеваний как возможность увеличения ожидаемой продолжительности жизни и здорового долголетия. Кардиоваскулярная терапия и профилактика. 2019. № 2. С. 5-12.

5. Ромейко В.Л., Потеряева Е.Л., Ивлева Г.П., Кругликова Н.В., Труфанова Н.Л. Основные проблемы совершенствования правовых механизмов сохранения профессионального здоровья работающего населения. Здоровье населения и среда обитания. 2018. Т. 307. № 10. С. 46-49.

6. Валеева Э.Т., Бакиров А.Б., Капцов В.А., Каримова Л.К., Гимаева З.Ф., Галимова Р.Р. Профессиональные риски здоровью работников химического комплекса. Анализ риска здоровью. 2016. № 3. С. 88-97.

7. Титова Е.Я., Голубь С.А. Современные проблемы охраны здоровья сотрудников крупного промышленного предприятия, работающих в условиях профрессиональных вредностей. Анализ риска здоровью. 2017. № 4. С. 83-90.

8. Шингаев С.М. Программы сохранения профессионального здоровья менеджеров в зарубежных странах. Ананьевские чтения - 2013. Психология в здравоохранении: материалы научной конференции (СанктПетербург, 22-24 октября 2013). 2013. С. 474-476.

9. Beare, P.G. Adult health nursing. Toronto: Elsevier Science, 1998. 1868 p.

10. Kok G., De Haes W. Research in health education and promotion. Hygie. 1991. Vol. 10. Is. 2. P. 12-15.

11. Арутюнов А.Т., Денисенко В.И., Турзин П.С., Ходжаев С.С. Профилактическая медицина и эпидемиология: энциклопедический словарь-справочник / под ред. Г.Г. Онищенко и В.И. Покровского. Москва; Смоленск, 2010. 756 с.

12. Миронов С.П., Арутюнов А.Т., Турзин П.С. Факторы риска заболеваний человека и их профилактика. Москва, 2008. 272 с.

13. Рыбаков И.А. Корпоративная культура и программы корпоративного здоровья для удаленных работников. Управление корпоративной культурой. 2015. № 3. С. 258-263.

14. Рыбаков И.А. Корпоративное здоровье: как мотивировать, повышать производительность труда и экономить, используя программы благополучия. Москва : Самиздат, 2018. 210 с.

15. Рыбаков И.А. Экономическая эффрективность программ по укреплению корпоративного здоровья, а также профилактических программ на рабочем месте для сотрудников с краткосрочной временной нетрудоспособностью. Биозащита и биобезопасность. 2015. № 1(22). С. 10-17.

16. Данилова Е.А. Проблема выбора стилей руководства в процессе фрормирования организационной культуры. Социокультурные фракторы консолидации современного российского общества: III Международная научно-практическая конференция / Под редакцией Г.Б. Кошарной, Н.В. Корж. Пенза, 2019. С. 51-55. 
17. Наумов А.И. Организационная культура как фрактор долгосрочной конкурентоспособности. Управление компанией. 2018. № 7. С. 52-60.

\section{REFERENCES:}

1. Scherbakova E.M. (2019) Naselenie mira po otsenkam OON peresmotra 2019 goda [World population estimated by UN revision 2019]. Demoskop Weekly, pp. 821-822. Available at: http://demoscope.ru/weekly/2019/0821/ barom01.php (accessed 21 September 2021).

2. Razumov A.N., Ponomarenko V.A., Piskunov V.A. (1996) Zdorove zdorovogo cheloveka (Osnovyi vosstanovitelnoy meditsinyi) [Health of a healthy person (Fundamentals of restorative medicine)] / pod red. V.S. Shinkarenko. Moscow: Meditsina. (in Russian)

3. Ushakov I.B., Arutyunov A.G., Shereshkov G.M., Turzin P.S. (2002) Vvedenie v aviatsionnuyu meditsinu [Introduction to Aviation Medicine]. Moscow; Voronezh. (in Russian)

4. Maslennikova G.Ya., Oganov R.G. (2019) Profilaktika neinfektsionnyih zabolevaniy kak vozmozhnost uvelicheniya ozhidaemoy prodolzhitelnosti zhizni i zdorovogo dolgoletiya [Prevention of noncommunicable diseases as an opportunity to increase life expectancy and healthy longevity]. Kardiovaskulyarnaya terapiya i profilaktika, no. 2, pp. 5-12.

5. Romeyko V.L., Poteryaeva E.L., Ivleva G.P., Kruglikova N.V., Trufanova N.L. (2018) Osnovnyie problemyi sovershenstvovaniya pravovyih mehanizmov sohraneniya professionalnogo zdorovya rabotayuschego naseleniya [The main problems of improving the legal mechanisms for maintaining the professional health of the working population]. Zdorove naseleniya i sreda obitaniya, vol. 307, no. 10, pp. 46-49.

6. Valeeva E.T., Bakirov A.B., Kaptsov V.A., Karimova L.K., Gimaeva Z.F., Galimova R.R. (2016) Professionalnyie riski zdorovyu rabotnikov himicheskogo kompleksa [Occupational health risks of employees of the chemical complex]. Analiz riska zdorovyu, no. 3, pp. 88-97.

7. Titova E.Ya., Golub S.A. (2017) Sovremennyie problemyi ohranyi zdorovya sotrudnikov krupnogo promyishlennogo predpriyatiya, rabotayuschih $v$ usloviyah professionalnyih vrednostey [Modern problems of health protection of employees of a large industrial enterprise working in conditions of occupational hazards]. Analiz riska zdorovyu, no. 4, pp. 83-90.

8. Shingaev S.M. (2013) Programmyi sohraneniya professionalnogo zdorovya menedzherov $\vee$ zarubezhnyih stranah [Professional health preservation programs for managers in foreign countries]. Proceedings of the Ananevskie chteniya. Psihologiya $v$ zdravoohranenii: materialyi nauchnoy konferentsii (Sankt-Peterburg, 22-24 oktyabrya 2013), pp. 474-476.

9. Beare P.G. (1998) Adult health nursing. Toronto: Elsevier Science, 1868 p.

10. Kok G., De Haes W. (1991) Research in health education and promotion. Hygie, vol. 10, is. 2, pp. 12-15.

11. Arutyunov A.T., Denisenko V.I., Turzin P.S., Hodzhaev S.S. (2010) Profilakticheskaya meditsina i epidemiologiya: entsiklopedicheskiy slovar-spravochnik [Preventive medicine and epidemiology: an encyclopedic dictionary] / pod red. G.G. Onischenko i V.I. Pokrovskogo. Moscow; Smolensk. (in Russian)

12. Mironov S.P., Arutyunov A.T., Turzin P.S. (2008) Faktoryi riska zabolevaniy cheloveka i ih profilaktika [Risk factors for human diseases and their prevention]. Moscow. (in Russian)

13. Ryibakov I.A. (2015) Korporativnaya kultura i programmyi korporativnogo zdorovya dlya udalennyih rabotnikov [Corporate culture and corporate health programs for remote workers]. Upravlenie korporativnoy kulturoy, no. 3, pp. 258-263.

14. Ryibakov I.A. (2018) Korporativnoe zdorove: kak motivirovat, povyishat proizvoditelnost truda i ekonomit, ispolzuya programmyi blagopoluchiya [Corporate health: how to motivate, increase productivity, and save with wellbeing programs]. Moscow: Samizdat. (in Russian)

15. Ryibakov I.A. (2015) Ekonomicheskaya effektivnost programm po ukrepleniyu korporativnogo zdorovya, a takzhe profilakticheskih programm na rabochem meste dlya sotrudnikov s kratkosrochnoy vremennoy netrudosposobnostyu [Cost-effectiveness of corporate health promotion programs and workplace prevention programs for employees with short-term temporary disabilities]. Biozaschita i biobezopasnost, no. 1(22), pp. 10-17.

16. Danilova E.A. (2019) Problema vyibora stiley rukovodstva v protsesse formirovaniya organizatsionnoy kulturyi [The problem of choosing leadership styles in the process of forming an organizational culture]. Proceedings of the Sotsiokulturnyie faktoryi konsolidatsii sovremennogo rossiyskogo obschestva: III Mezhdunarodnaya nauchno-prakticheskaya konferentsiya / Eds. G.B. Kosharnoy, N.V. Korzh. Penza, pp. 51-55.

17. Naumov A.I. (2018) Organizatsionnaya kultura kak faktor dolgosrochnoy konkurentosposobnosti [Organizational culture as a factor in long-term competitiveness]. Upravlenie kompaniey, no. 7, pp. 52-60. 